\title{
Topical Issues of Strategic Planning and Audit in Modern Russia
}

\author{
A. B. Zolotareva ${ }^{a}$ and I. A. Sokolov ${ }^{b, *}$ \\ ${ }^{a}$ Gaidar Institute for Economic Policy, Moscow, Russia \\ ${ }^{b}$ Institute of Applied Economic Research, Russian Presidential Academy of National Economy and Public Administration under \\ the President of the Russian Federation, Moscow, Russia \\ *e-mail: sokolov-ia@ranepa.ru \\ Received March 17, 2021; revised March 24, 2021; accepted April 8, 2021
}

\begin{abstract}
The article analyzes the state of strategic planning and audit in the Russian Federation. There is a low level of implementation of the country's main strategic documents, which is due to the insufficient realism of their goals. In turn, the shortcomings of strategic documents are largely a consequence of the lack of regulatory rulemaking and the closed nature of the procedure for their development. Strategic audit in Russia is still not effective enough, since the practical significance of the recommendations of the Accounts Chamber is not great-the problems it reveals cannot be eliminated at the stage of implementation of strategic documents, and it is actually excluded from participation in their development. Based on the results of the analysis, the authors formulate proposals on the areas of improving the procedures for strategic planning and audit.
\end{abstract}

Keywords: strategic planning, strategic audit, national goals, national projects, strategic planning documents DOI: $10.1134 / \mathrm{S} 1075700721050154$

Origins of strategic planning and audit in the Russian Federation. The concepts of "strategic planning" and "strategic audit" in Russian legislation are innovations of the last decade. The term "strategic planning" first appeared in item 1 of article 3 of the Federal Law of June 28, 2014, No. 172-FL, On Strategic Planning in the Russian Federation (hereinafter referred to as the Law on Strategic Planning) and was defined as "the activity of participants in strategic planning in goalsetting, forecasting, planning and programming socioeconomic development of the Russian Federation ...."

The orientation towards the development of strategic audit or strategic approach to audit is one of the newest global trends in the activities of supreme audit institution (which in the Russian Federation are called financial control bodies). Although the international organization of supreme audit institutions (INTOSAI) has not yet developed a generally accepted definition of these terms, an idea of their content can be obtained from its documents. Thus, in the INTOSAI Moscow Declaration, adopted at the XXIII Congress, held in Moscow in 2019, supreme audit institutions (hereinafter referred to as SAIs) are urged to "develop a strategic approach to public audit in order to support the achievement of national priorities and SDGs," i.e., sustainable development goals formulated by the UN [1]. "This implies, among other things: (1) conducting a set of audits aimed at assessing the government's ability to achieve its goals; (2) assessment of the maturity of the strategic management system (setting goals, linking strategies with national goals, 'feedback' and proper control based on the results obtained)" [2]. However, the use of the words "among other things" in this formulation indicates that it does not purport to be an exhaustive description of the objectives of strategic audit.

Various approaches to the definition of strategic audit can also be found in domestic scientific literature and legislation. For example, the following definition of strategic audit in one of the scientific articles seems to be quite successful, although not devoid of shortcomings: "the type of control, with the help of which it is possible to obtain an objective assessment of the available material, financial, intellectual and other resources, necessary to make optimal strategic decisions, as well as to determine the efficiency of public resource management in the interests of implementing the strategy of socioeconomic development of the country and its territories" [3]. More concise and at the same time complete is the definition in part 7 of article 14 of the Federal Law of April 5, 2013, No. 41FL, On the Accounts Chamber of the Russian Federation (hereinafter referred to as the Law on AC), where strategic audit is determined through its goal, which is stated as "an assessment of the feasibility, risks and results of achieving the goals of the socioeconomic development of the Russian Federation, provided for by the strategic planning documents."

With all the variety of approaches to defining strategic audit, its key feature is the participation of SAIs in the development and control over the implementation of national strategic planning documents. How- 
ever, from the standpoint of the classical theory of separation of powers, the idea of strategic audit is not indisputable, since the check and balance system does not allow the possibility of combining the functions of making political decisions and monitoring their implementation [4].

In developing the idea of strategic audit, INTOSAI is aware of its weaknesses, emphasizing that: "strategic perspective and forward-looking analysis involve considering issues where the boundaries between technical directive decisions and policy choices that SAIs should always try to avoid, are blurred. The challenge is to establish a clear line between performance measurement, provision of advice, and what may be perceived as interfering with policy issues" [2]. Although from the document it is not clear where this line lies, it is clear that INTOSAI does not allow binding SAIs' conclusions on the results of the strategic audit. This approach seems to be correct, since otherwise SAIs would actually replace those bodies of legislative or executive power that are empowered to approve strategic documents.

At the same time, the recommendatory nature of the SAIs' conclusions based on the results of the strategic audit does not diminish their importance, which is predetermined by the SAIs' weight in the political system of any democratic state. It seems that the special authority of SAIs is due to two factors ensured by the INTOSAI principles [5]: on the one hand, the independence of SAIs from the executive branch, on the other hand, the high professionalism of their employees, most of whom work on a permanent basis. The last factor should not be underestimated, since in the modern world an important "competitive advantage" of the executive branch in comparison with the legislative branch is the irremovability of middle and lower-level officials. With the existing level of knowledge specialization, the turnover inherent in the legislative branch adversely affects the level of its competence.

The special role of control bodies in the political system of the state was first noted back in 1924 in Sun Yat-sen's work "The Constitution of the Five Powers" [6]. The author argued with the classical (Western) theory of separation of powers, believing that three powers are not enough to ensure an effective check and balance system. In his opinion, to the three branches of power, allocated by Sh.L. Montesquieu, two more should be added: examination ${ }^{1}$ and control. In our opinion, there is currently no point in identifying a special "examination authority," the task of which is to select applicants for positions of officials, since the competitive procedure for occupying such positions and objective selection criteria are enshrined

\footnotetext{
${ }^{1}$ Singling out "examination authority", Sun Yat-sen drew on the experience of his country: from 605 to 1909 , in accordance with Confucianism, China had a system of state examinations for officials of all levels.
}

in the legislation of most developed countries. However, the idea of separating the bodies exercising control over the executive branch into a separate category, expressed almost 100 years ago, is not only not outdated, but has acquired particular relevance in connection with the development of strategic audit. This idea is shared by many domestic legal experts [7-11], not considering it possible to refer the Accounts Chamber (as well as some other federal authorities, including the General Prosecutor's Office of the Russian Federation, the Central Election Commission of Russia and the Central Bank of the Russian Federation) to any of the three traditional branches of government.

Analysis of the implementation of top-level Russian strategic documents. The Accounts Chamber of the Russian Federation (hereinafter referred to as the Accounts Chamber) is one of the initiators of the use of strategic audit in the activities of SAIs. Back in 2014, it achieved the inclusion of a strategic audit in the list of its powers, from the same year it began to audit state programs for their compliance with the socioeconomic priorities of the country's development ${ }^{2}$, and in 2019 started monthly monitoring of the achievement of national projects and goals ${ }^{3}$. In addition to monitoring the implementation of strategic documents, the Accounts Chamber is empowered to participate in their development. The scale of activities of the Accounts Chamber in the field of strategic audit is impressive, in fact it has become for society one of the main suppliers of objective information on the implementation of government goals. However, this information does not always inspire optimism. So, in most reports on the results of the audit of state programs and national projects, incomplete correspondence between the goals of these programs (projects) and national goals is noted, and the possibility of achieving a number of goals is questioned. For example, according to the estimates of the Accounts Chamber, in 2020 there are risks of not reaching the values of over 280 indicators of the effectiveness of state programs, which is more than $19 \%$ of their total number ${ }^{4}$.

The report on the implementation of the Education national project for 2020 states that it does not reflect events that are significant from the point of view of the contribution of education to the socioeconomic development of the Russian Federation, including: the task of reducing inequality in the quality of educational results has not been set between schools and student groups and to overcome educational failure; there are no activities aimed at the formation of entrepreneurial skills, overcoming the personnel

\footnotetext{
${ }^{2}$ Report on the work of the Accounts Chamber of the Russian Federation in 2019. https://ach.gov.ru/reports/10114.

${ }^{3}$ Monitoring the achievement of national goals. https://ng.ach.gov.ru/.

${ }^{4}$ Report on the work of the Accounts Chamber of the Russian Federation in 2019. P. 39. https://ach.gov.ru/reports/10114.
} 
shortage in educational organizations, or the introduction of modern teaching technologies into the main educational programs and the creation of a system of motivating citizens to be included in the system of continuous education ${ }^{5}$. But the main conclusion of the report is that the expenditures of the budgetary system of the Russian Federation on education in the amount of $3.6 \%$ of GDP planned for 2019-2021 annually do not exceed the level of 2015-2017, which is "insufficient to ensure competition with countries leaders in the field of educational technologies." 6

The greatest concern in the reports of the Accounts Chamber on the results of the audit of state programs is caused not so much by the shortcomings of these programs or the process of their implementation, but by reports of the lack of feedback on the indication of these shortcomings. For example, the following phrase from the report of the Accounts Chamber for 2019 is quite typical: "The Accounts Chamber annually pays attention to the shortcomings of the formation and implementation of state programs of the Russian Federation. So, the indicators of a number of state programs do not fully correspond to the indicators of strategic documents, the forecast of the socioeconomic development of the Russian Federation, for a number of state programs there is no interdependence between changes in the amount of funding and the goals, objectives and expected results, connection with other state programs, the interconnection of tasks, activities of state programs with indicators is not fully ensured."7 In the report on the implementation of the state program "Health Service" for 2020, it is noted that the program passport does not take into account the tasks provided for by the Decree of the President of the Russian Federation of May 7, 2018, No. 204, On National Goals and Strategic Objectives of the Development of the Russian Federation for the Period until 2024: an increase in life expectancy by 2024 to 78 years and an increase in the satisfaction of the population with the quality of medical care by 2025 to $54 \%$, "although the Accounts Chamber has repeatedly pointed out this fact." 8 The Government also does not respond to signals from other regulatory bodies: "The Ministry of Economic Development of Russia annu-

\footnotetext{
${ }^{5}$ Report on the interim results of the expert and analytical event Monitoring the implementation of the activities of the national project "Education" necessary to fulfill the tasks set in the Decree of the President of the Russian Federation of May 7, 2018, No. 204, On National Goals and Strategic Objectives of the Development of the Russian Federation for the Period until 2024. https://ach.gov.ru/upload/iblock/9f3/9f381090ef30beaa53a5ff1 4018ab4aa.pdf.

${ }^{6}$ Ibid, p. 39.

${ }^{7}$ Report on the work of the Accounts Chamber of the Russian Federation in 2019, p. 27. https://ach.gov.ru/reports/10114

${ }^{8}$ Report of the Accounts Chamber on the results of the implementation of the SP "Health Service" in 2019, p. 7. https://ach.gov.ru/upload/iblock/7ad/7ad85906c0b0ed5c5818d 2df4a46f312.pdf.
}

ally assesses the effectiveness of the implementation of state programs, the analysis of which indicates an increase in the volume of ineffective expenditures on state programs, i.e., without achieving the planned results. However, the results of this assessment are hardly ever used when adjusting state programs, despite the presence of relevant norms in the budgetary legislation." 9

The least favorable picture is the implementation of top-level strategic documents-decrees of the President of the Russian Federation. Problems were observed even with the implementation of the decrees of May 2012. According to the data of the Accounts Chamber, by the end of 2018, a number of key indicators of these decrees were not achieved, including:

-An increase in the volume of investments to $27 \%$ of GDP by 2018 (the actual value of the indicator in 2018 was $20.6 \%$ of GDP).

-An increase in labor productivity by 1.5 times by 2018 relative to the level of 2011 (Rosstat noted the lack of sustainable growth in labor productivity from 2014 to 2017).

-An increase in the share of products of high-tech and science-intensive sectors of the economy to $25.6 \%$ of GDP by 2018 (the actual value of the indicator in 2018 was $21.3 \%$ of GDP).

-An excess of the average interest rate on mortgage housing construction in relation to the consumer price index was planned to be brought to a level of no more than $2.2 \mathrm{pp}$ (the actual value of the indicator in 2018 was $5.3 \mathrm{pp})^{10}$.

The situation is even worse with the implementation of the Decree of the President of the Russian Federation of June 7, 2018, No. 204, On National Goals and Strategic Objectives of the Development of the Russian Federation for the Period until 2024 (hereinafter referred to as Decree No. 204). According to the latest available data from the monitoring of national goals for September 2020, carried out by the Accounts Chamber, the following picture was observed (see Table 1).

As follows from the analysis of the table, for four of the nine national goals (population growth, growth of incomes and pensions, improvement of housing conditions, economic growth in terms of GDP growth) over the two years that have passed since the release of this Decree, negative dynamics were observed, for three more (poverty reduction, accelerated technological development and digital technologies)-zero dynamics. The growth rates of indicators for the two remaining goals (life expectancy growth and export development) are such that if they are maintained in the future, these goals will also not be achieved. The

\footnotetext{
${ }^{9}$ Report on the work of the Accounts Chamber of the Russian Federation in 2018, pp. 26-27. https://ach.gov.ru/promo/ annual-report-2018/annual-report-2018.pdf.

${ }^{10}$ Ibid, p. 24.
} 
Table 1. Monitoring of the achievement of national goals as of September 7, 2020

\begin{tabular}{|c|c|c|c|}
\hline National goal & Base value (2018) & Reporting period & Target state (by 2024) \\
\hline Population growth & -224.6 thousand people & -316.3 thousand people & 1.0 thousand people \\
\hline Life expectancy growth & 72.9 years & 73.3 years & 78.0 years \\
\hline Growth in income and pen- & Income: $+0.1 \%$ & Income: $-3.7 \%$ & Income: $2.4 \%$ \\
\hline sions & Pensions: $+0.8 \%$ & Pensions: $+3.0 \%$ & $\begin{array}{l}\text { Pensions: a steady rise in the } \\
\text { level of pension provision } \\
\text { above the inflation rate }\end{array}$ \\
\hline Poverty reduction & $12.6 \%$ & $12.6 \%$ & $6.6 \%$ \\
\hline $\begin{array}{l}\text { Improvement of housing } \\
\text { conditions (annually) }\end{array}$ & 3.5 million people & 3.4 million people & 5.0 million people \\
\hline $\begin{array}{l}\text { Acceleration of technological } \\
\text { development }\end{array}$ & $19.8 \%$ & $19.8 \%$ & $50.0 \%$ \\
\hline Digital technologies & $1.7 \%$ & $1.7 \%$ & $5.1 \%$ \\
\hline \multirow[t]{3}{*}{ Economic growth } & GDP rate: $2.5 \%$ & GDP rate: $-3.6 \%$ & GDP rate: $3.3 \%$ \\
\hline & Inflation: $4.3 \%$ & Inflation: $3.6 \%$ & Inflation: $\leq 4.0 \%$ \\
\hline & GDP by PPP: 6th place & GDP by PPP: 6th place & GDP by PPP: 5th place \\
\hline Export development & 215.6 billion dollars & 217.9 billion dollars & 350.0 billion dollars \\
\hline
\end{tabular}

Source. Data of the Accounts Chamber of the Russian Federation. https://ng.ach.gov.ru/.

threat of noncompliance with the Decree, even in the context of the outbreak of the global economic crisis due to the coronavirus pandemic, required its correction after two years of implementation (which clearly does not meet the requirements for long-term goalsetting). On July 21, 2020, the president of the Russian Federation issued the Decree No. 474, On the National Development Goals of the Russian Federation for the Period until 2030 (hereinafter referred to as Decree 474), which extended the period for achieving previously set goals by six years and at the same time reduced the values of some indicators. For example, if originally it was supposed to reach life expectancy at the level of 80 years by 2024, now it is 78 years by 2030 . The reduction of the poverty level to about $6.5 \%$ is postponed until 2030, although in accordance with the Concept of long-term social economic development of the Russian Federation, approved by the Government of the Russian Federation in 2008, this indicator should have been achieved as early as $2020^{11}$. If in 2018 the Decree No. 204 set out the goal of ensuring a sustainable growth in real incomes of citizens, as well as an increase in the level of pension provision above the inflation level, then in the Decree 474 in 2020, it is not necessary to ensure the growth of incomes of the population and the level of pension provision not lower than inflation. Not immediately noticeable differences between these formulations are fundamental,

\footnotetext{
${ }^{11}$ Order of the Government of the Russian Federation of November 17, 2008, No. 1662-r, On the Concept of Long-Term Socioeconomic Development of the Russian Federation for the Period until 2020 (together with the Concept of Long-Term Socioeconomic Development of the Russian Federation for the Period until 2020).
}

since the growth of income at the inflation rate means the absence of its growth. The tasks of ensuring the entry of the Russian Federation into the five largest economies in the world and increasing the number of organizations carrying out technological innovations to $50 \%$ of their total number were completely abandoned.

It seems that the main reason for the low level of implementation of the country's main strategic documents is the lack of realism (or excessive ambition) of their goals, which, in turn, is largely due to the lack of regulatory rulemaking and the closed nature of the procedure for developing these documents. It is significant that the decrees of the President of the Russian Federation, which "in fact ... have now replaced a fullfledged strategy of the country's development in Russia," 12 are not even mentioned in the list of federal strategic planning documents in part 3 of article 11 of the Federal Law On Strategic Planning in the Russian Federation. National projects do not appear in this list either, which, in accordance with subitem "B" of item 2 of the Decree No. 204 should become the main instrument for achieving the goals set in it. National projects are approved by the Council for Strategic Development and National Projects, an advisory body under the President of the Russian Federation, which is not provided for by the Constitution, the activities of which are regulated by a three-page Regulation approved by the decree of the president of the Russian Federation. ${ }^{13}$

\footnotetext{
${ }^{12}$ Digest of monitoring of national goals. July 2020. The opinion of the expert Boris Zhikharevich, p. 6. https://ach.gov.ru/auditnational/daydzhest-04-08-2020.
} 
What documents are provided for by the Law On Strategic Planning in the Russian Federation? The first in the hierarchy of federal strategic documents are the annual message of the President of the Russian Federation to the Federal Assembly and the strategy of social and economic development of the Russian Federation. In our opinion, elevating the message of the President of the Russian Federation to the Federal Assembly to the rank of the country's main strategic document is illogical, since it is not without reason that this message is called annual, i.e., it cannot set long-term goals and serve as a starting point for developing a strategy for the socioeconomic development of the Russian Federation, which is approved for a period of at least six years ${ }^{14}$. The second most important strategic planning document-the strategy of socioeconomic development of the Russian Federation-has not been adopted six years after the adoption of the Law On Strategic Planning in the Russian Federation.

It turns out that the documents that the Law On Strategic Planning in the Russian Federation puts at the forefront in the process of strategic planning either do not exist at all, or, by their very nature and content, are not able to fulfill their assigned role. At the same time, in practice, strategic planning is carried out on the basis of documents that are not provided for by law, the development of which takes place behind closed doors without involving not only the public, but also those authorities that, according to the letter of the law, should take an active part in preparation and examination of the highest strategic planning documents. The bodies excluded from participation in the development of really effective strategic planning documents (i.e., decrees of the President of the Russian Federation and national projects), in addition to representatives of the legislative authority, include the entire financial and economic block of the government, although the Ministry of Economic Development of Russia and the Ministry of Finance of Russia, according to the law On Strategic Planning in the Russian Federation, is responsible for the preparation and approval of forecast documents, which should serve as the basis for the development of the main planning document-the Strategy of Socioeconomic Development of the Russian Federation. Thus, the Ministry of Economic Development of Russia, according to this law, develops a long-term draft forecast of socioeconomic development, which, among other things, includes the definition of options for internal and external conditions for the socioeconomic development of the Russian Federation, and the Ministry of

\footnotetext{
${ }^{13}$ Decree of the President of the Russian Federation of July 19, 2018, No. 444, On Streamlining the Activities of Deliberative and Advisory Bodies under the President of the Russian Federation (together with the Regulations on the Council under the President of the Russian Federation for Strategic Development and National Projects).

${ }^{14}$ Part 1 of article 24 of the Federal Law On Strategic Planning in the Russian Federation.
}

Finance of Russia-a draft budget forecast for a longterm period, which contains, among other things, a forecast of the main characteristics of the consolidated budget of the Russian Federation. Thus, according to the logic of the Law On Strategic Planning in the Russian Federation, this planning must comply with the principle of realism, i.e., be based on an assessment of the achieved level of development in various areas, as well as conditions, constraints and available resources for progress in these areas.

However, some of the goals set in the May decrees of the President of the Russian Federation give the impression of political declarations that are not coordinated with the real possibilities of the country. This applies, for example, to such goals of the 2012 decrees as the creation of 25 million high-tech jobs or an outstripping increase in salaries for public sector employees, which experts recognize as unrealistic in the face of a sharp economic slowdown, "taken out of the context of institutional constraints." [12]. Moreover, there were obvious errors in the initial version of the Decree No. 204, which, of course, would not have happened if the draft of this Decree had passed the usual examinations and approvals, which are mandatory for documents of this level. For example, the goal was to ensure "sustainable natural population growth" by increasing the total fertility rate to 1.7. Meanwhile, "sustainable natural population growth is possible only if the total fertility rate is stable at a level of at least 2.1, and this is not realistic not only for Russia, but for the overwhelming majority of developed countries." 15

Despite the fact that the Decree No. 474, the adoption of which in July 2020 was a reaction to the threat of noncompliance with Decree No. 204, extends the implementation period and lowers some of the target indicators of the latter, which increases the likelihood of their achievement, previously expressed considerations of insufficient substantiation and the realism of the strategic decrees of the President of the Russian Federation are also applicable to the Decree No. 474. First of all, because this decree did not reduce, but increased the number of national goals in comparison with the Decree No. 204, in which national goals with quantitatively measurable indicators were contained in item 1, which consisted of nine subitems-the very ones, the monitoring results of which are given in Table 1. Other quantitatively measurable indicators were contained in other items of this decree, listing the requirements for the content of national projects to be developed, and played a secondary role, since they could be subject to correction in the process of developing national projects or "get lost" among their other indicators, and also because summary data on monitoring the implementation of all national projects are not published.

\footnotetext{
${ }^{15}$ Digest of monitoring of national goals. July 2020. The opinion of the expert Anatoly Vishnevsky. P. 11. https://ach.gov.ru/audit-national/daydzhest-04-08-2020.
} 
In the Decree No. 474, the number of indicators for achieving national goals increased from 9 to 22 (item 2 of the Decree). And although most of these indicators are not new, since their analogs were present in previously approved national projects and state programs, the very fact of their fixation among national goals markedly increases their significance. An increase in the status of these indicators, it would seem, presupposes the need for a deep preliminary analysis of their quality and dynamics over the two years that have passed since the issuance of the Decree No. 204. However, it does not seem that such a deep analysis was carried out.

For example, among the national goals in the Decree No. 474, Russia is included in the top ten countries in the world in terms of the quality of general education (paragraph 2, subitem "b", item 2). Earlier, this goal was fixed by the state program and the national project "Education," and its achievement was assessed by the weighted average rating of Russia based on the results of three international studies (PISA, TIMSS, PIRLS) ${ }^{16}$. At the same time, the Accounts Chamber drew attention to the incomparability of the methods, the cycle of these studies and the circle of countries participating in them, and therefore considered it incorrect to use this indicator to characterize the achievement of the goal of the national project ${ }^{17}$. In addition, in 2018 the target value of this indicator was not achieved ${ }^{18}$, there was no data on the actual value of this indicator in the reporting on the progress of the program implementation for $2019^{19}$, and experts noted the deterioration of Russia's rating according to the results of some of the abovementioned international studies. For example, according to the PISA study, "Russian schoolchildren showed the best results in the early 2010s. In 2018, Russia showed indicators

\footnotetext{
${ }^{16}$ PISA (Program for International Student Assessment)-international program for the assessment of educational achievements of students. TIMSS (Trend in Mathematics and Science Study)-international monitoring study of the quality of school and science education. PIRLS (Progress in International Reading Literacy Study) - international study of the quality of reading and text comprehension.

${ }^{17}$ Report on the interim results of the expert and analytical event "Monitoring the implementation of the activities of the national project "Education" necessary to fulfill the tasks set in the Decree of the President of the Russian Federation of May 7, 2018, No. 204, On National Goals and Strategic Objectives of the Development of the Russian Federation for the Period until 2024, pp. 15-16. https://ach.gov.ru/upload/iblock/9f3/ 9f381090ef30beaa53a5ff14018ab4aa.pdf.

${ }^{18}$ According to the Annual Report on the Implementation of the Pilot State Program of the Russian Federation "Development of Education" for 2018, it was 14.9 against the planned 14 . https://docs.edu.gov.ru/document/630652105614623426d6674a7f4cc37c/download/1123/.

${ }^{19}$ Analysis of the implementation of the state program "Development of Education" in the framework of the conclusion on the Government report on the execution of the federal budget of 2019. P. 12 https://ach.gov.ru/upload/iblock/ef4/ef4d897bdde7509fe 164b885f8ce5bb7.pdf.
}

lower than in 2015 and lower than the average for all OECD countries. At the same time, no specific management initiatives aimed at solving this problem have been observed since the issuance of previous decrees." 20

In the Decree No. 474, conditionally new targets are declared. Among them, first of all, one should note the real growth of investments in fixed assets of at least $70 \%$ by 2030 compared with the indicator of 2020 . However, earlier in the Decree of the President of the Russian Federation of May 7, 2012, No. 596, On Long-Term State Economic Policy, the task was to ensure the growth of investments up to $25 \%$ of GDP by 2015 and up to $27 \%$ by 2018 . De facto, this indicator in these years was equal to $20 \%$ of GDP, and in 2019 $20.6^{21}$. The indicator for 2020 is still unknown (in the first half of the year it was $96 \%$ of the same period in 2019 ), but it is unlikely that it will exceed $20 \%$ of GDP under the crisis conditions. Consequently, it can be argued that the dynamics of growth of investments in fixed assets coincided, or even lagged somewhat behind the rates of economic development of the country, which in the 2010 s did not exceed $1.8 \%$ per year on average. At the same time, in order to increase the real volume of investments in fixed assets by $70 \%$ over a decade (from 2020 to 2030), an average annual growth rate of more than $5 \%$ will be required, which hardly looks realistic.

Another new ambitious goal of the Decree No. 474 is to "improve the quality of the urban environment by one and a half times." Earlier in subitem " $\mathrm{B}$ " of item 6 of the Decree No. 204, the aim was set to "increase the urban environment quality index by $30 \%$." If we neglect the vague differences between the terms "quality of the urban environment" and "index of the quality of the urban environment", this means an increase in the target indicator by five times! At the same time, according to the estimates of the Accounts Chamber, even in the previous version of the national project "Housing and Urban Environment," the financial needs of the regions were not fully taken into account, and therefore, to improve the quality of the urban environment by one and a half times "it will be necessary not only to adjust the main tasks and activities of the national project 'Housing and Urban Environment' and the federal program 'Formation of a Comfortable Urban Environment,' but also to revise the financial policy for the implementation of these projects." 22

Another new goal of the Decree No. 474 is to increase the number of visits to cultural events by three

\footnotetext{
${ }^{20}$ Digest of monitoring of national goals. July 2020 . The opinion of the expert Viktor Vashtein. P. 21. https://ach.gov.ru/auditnational/daydzhest-04-08-2020

${ }^{21}$ Share of investments in fixed assets in gross domestic product. https://rosstat.gov.ru/folder/11186.

${ }^{22}$ Digest of monitoring of national goals. July 2020. P. 26. https://ach.gov.ru/audit-national/daydzhest-04-08-2020.
} 
times compared to 2019. In addition to objective obstacles to achieving this indicator in the context of the coronavirus pandemic and the periodically introduced self-isolation regime (which was in effect at the time of the Decree's release), the advisability of using this indicator as a criterion for cultural growth in the absence of a distinction between poetry evenings and discos raises doubts.

Finally, the Decree No. 474 includes some new goals, the achievement of which cannot be measured. This applies, for example, to such an indicator as an increase of up to $70 \%$ in the share of citizens who systematically go in for physical culture and sports. Considering that the share of citizens able to engage in physical education and sports usually does not exceed $70 \%$, to achieve this indicator, it is necessary that all citizens (with the exception of infants, the elderly and the disabled) systematically engage in physical education and sports. But since statistics do not record exercises at home or jogging in the park, it is impossible to check the achievement of this indicator.

Thus, in the Presidential Decree No. 474, designed to increase the possibility of achieving previously announced strategic goals, new or conditionally new goals were included, the validity and feasibility of which raises serious doubts.

According to the Law on the Accounts Chamber, an important guarantee of the quality of strategic planning documents should be the participation of the Chamber in their development. In accordance with this Law, the Accounts Chamber conducts an examination and gives opinions on the documents of strategic planning of the Russian Federation, including on draft state programs (federal target programs) (items 5 and 6 of part 1 of article 24), prepares recommendations on the formation of a system of target indicators for the development of strategic planning documents of the Russian Federation, as well as on their composition and quantitative values (item 10, part 1, article 14). However, all the listed powers of the Accounts Chamber have no practical significance, since the documents in the preparation of which it participates are purely secondary. As mentioned above, national goals are set by decrees of the president of the Russian Federation and national projects, the development of which takes place without the participation of the Accounts Chamber.

Towards meaningful strategic planning and auditing. The analysis leads to the conclusion that the current strategic planning procedure in Russia is predominantly closed and partly voluntary, which negatively affects the level of elaboration of strategic documents and reduces the likelihood of achieving their goals. What can be done to improve the quality of strategic planning in Russia?

The minimum necessary measure seems to be the return of this process to the legal field, i.e., bridging the gap between the prescribed legislation and the actual procedure for strategic planning in Russia. Regardless of which body approves the main strategic document of the country, the procedure for its development should be legislatively regulated and ensure its compliance with scientifically based forecasts of socioeconomic development, including the forecast of the amount of budgetary resources available for the implementation of national goals in the planning period. It is also extremely important that the assessment of the feasibility of forecasts of available resources, national goals and methods of achieving them, formulated in the draft of the main strategic document, prior to its approval, should be carried out not only by the executive authorities, but also by institutions independent of them, first of all by the Accounts Chamber.

If the decree of the president of the Russian Federation remains the main strategic document of the country, reflecting his program upon accession, it seems expedient to adjust the format of this document, shifting the emphasis towards greater validity and realism of long-term development goals and greater certainty of ways to achieve them. The strategic decrees of the president issued so far $(2012,2018,2020)$ contained neither the projections of the required budgetary resources, nor any specific program of measures aimed at achieving the set goals. The main content of the decrees is the final target indicators for the development of various sectors of the economy and the social sphere, as well as instructions to the Government of the Russian Federation "to develop a set of measures" to achieve these indicators. In those cases when strategic decrees provided for specific measures, they, as a rule, had a very indirect relation to the achievement of the ambitious goals of the decrees. For example, in the Decree of the President of the Russian Federation of May 7, 2012, No. 597, On Measures for the Implementation of State Social Policy, among others, the task was to ensure an increase of the size of real wages by $1.4-1.5$ times by 2018 , but among measures that could at least somehow influence the achievement of this indicator in the private sector only these were mentioned: the approval of professional standards (subitem " $d$ " of item 1), the development of uniform principles for assessing the professional training of workers (subitem " $\mathrm{e}$ " of item 1) and the expansion of the participation of employees in the management of organizations (subitem " $h$ " of item 1 ). By the Decree No. 204, in addition to achieving target indicators in various areas, the Government of the Russian Federation prescribes the solution of certain tasks, however, these tasks in most cases are formulated in the form of general principles, development directions that do not have measurable benchmarks. For example, in the first edition of the Decree No. 204, in order to achieve "sustainable natural population growth", the Government of the Russian Federation set the following tasks: 
-Introduction of means for financial support of families at the birth of children.

- Creating conditions for women with children to work, including achieving 100 percent accessibility (by 2021) of preschool education for children under the age of three.

-Development and implementation of a program of systematic support and improvement of the quality of life of older citizens.

-Formation of a system of motivation of citizens for a healthy lifestyle, including healthy eating and giving up bad habits.

- Creating conditions for all categories and groups of the population for practicing physical culture and sports, mass sports, including increasing the level of provision of the population with sports facilities, as well as preparing a sports reserve (subitem " $b$ " of item 3 of the Decree No. 204).

Of the five listed tasks, four are, if one may say so, of an immanent nature, that is, some means of financial support for families with children, citizens of the older generation, stimulation of physical education, etc. have existed for a long time and will always exist, which means that if the target in the form of "sustainable natural population growth" is not achieved, the Government of the Russian Federation cannot be blamed for not fulfilling its tasks. It will always be possible to refer to "objective obstacles."

It follows from this that in order to increase the level of feasibility of the strategic decrees of the President of the Russian Federation, it is necessary to ensure the specification of the tasks envisaged by them. Of course, we are not talking about including strategies for the development of individual sectors of the economy and social sphere in the decrees of the President of the Russian Federation. But until a sufficiently specific list of measures appears in the decrees, due to which it is supposed to achieve certain goals, the decrees are doomed to remain a set of good wishes, divorced from reality.

However, compliance with the three conditions listed above-legislative regulation of the procedure for developing decrees of the president of the Russian Federation on national goals, expanding the circle of participants in this procedure and specifying the content of these decrees-is still not enough for their successful implementation.

In our opinion, the main problem of strategic planning in Russia is that the ambitiousness of goals, even in spite of the evident, initially obvious risks of their failure, dominates the realism of their achievement. Instead of progressive, step-by-step development through a series of rather modest but achievable tasks, the authorities prefer to make public more ambitious goals, neglecting the risks of their failure. One of the reasons for this situation is that until 2019, when the Accounts Chamber began to publish data on monitoring national goals, objective information on their achievement was difficult to access. The official website of the President of the Russian Federation does not have a special section containing data on the implementation of his program decrees. On the website of the Government in the section "Orders" there are subsections on the implementation of the decrees of the President of the Russian Federation of 2012 and 2018 , however, instead of generalized statistical information in the format "plan-fact," the section is filled with random news reports on the activities of the Government of the Russian Federation, moreover, fairly outdated. For example, at the beginning of November 2020 , the most recent "news" of the subsection was a message dated June 21, 2019, about the clarification of the rules of operation of the "project financing factory." 23

Some indicators of the implementation of the decrees of May 2012 were published by Rosstat, however, experts noted that "the use of strict control mechanisms to achieve unrealistic goals at any cost led to adjustments in the methodology for calculating indicators in order to prevent the failure of the decrees" [12]. Representatives of the HSE clarified that a significant change in the calculation methods was made in terms of such indicators as the creation of 25 million jobs, coverage of citizens with public services on the principle of "one window," etc. [13].

Objective information on the achievement of the goals of the Decree No. 204 in a convenient form was contained only on the website of the Accounts Chamber, however, since September 2020, it has ceased to be published "in connection with the adjustment of national goals and national projects in accordance with the Decree No. 474." Instead of data on the achievement of national goals, data on the implementation of budget expenditures on national projects are now published ${ }^{24}$, which, of course, is not the same thing at all.

What conclusions follow from this? First of all, it is advisable to regulate the source and format of the official reporting on the implementation of the strategic goals of the Government of the Russian Federation. The Accounts Chamber should act not as the only "supplier" of such information, but as an expert on information coming from the executive branch.

In addition, the executive power, concerned about the statistics of the fulfillment of its strategic goals, should address the root cause of their failure, which, in our opinion, is the lack of financial resources for these goals. In the presence of severe budget constraints (including as a result of following the budget rule), strategic documents of the top level to achieve real growth in certain sectors of the economy or social sphere should ensure the concentration of funds and efforts in a small number of areas (no more than 5-7).

23 http://government.ru/orders/selection/696/.

24 https://ach.gov.ru/audit-national. 
And although, subject to the above conditions, the strategic decrees of the president of the Russian Federation can successfully fulfill the role of the highest documents of strategic planning, it seems more rational to approve the strategic priorities of the country's development at the legislative level. Firstly, because in a democratic state the highest strategic planning documents, in our opinion, should be the subject of consensus of the representative and executive branches of government, which is achieved by the legislative procedure for their adoption. Secondly, because the elimination of legislators from participating in the development of strategic documents is fraught with problems in the process of their implementation, since no budget expenditures are possible without parliamentary approval. And most importantly, only the legislative procedure for approving strategic planning documents can increase the practical role of the strategic audit carried out by the Accounts Chamber, the theoretical value of which (as shown in this article) is quite large. In conditions when the conclusions of the Accounts Chamber based on the results of a strategic audit are not binding, the executive branch, which has the right to independently approve strategic planning documents, may ignore its opinion. But if the supreme strategic planning documents are approved by law, the executive branch will have to take into account the opinion of the Accounts Chamber in order to ensure parliamentary support for the relevant draft laws.

It is quite obvious that Russia is only at the very beginning of the way towards establishing meaningful, rather than formal, strategic planning and audit. At the same time, this way should be taken without expecting quick success. But, as Confucius said, "no matter how fast you move towards your goal, the main thing is not to stop" [14].

\section{FUNDING}

The article was prepared as part of the research work of the state assignment of the RANEP and the State Council.

\section{REFERENCES}

1. Technical Report by the Bureau of the United Nations Statistical Commission (UNSC) on the Process of the Development of an Indicator Framework for the Goals and Targets of the Post-2015 Development Agenda (Working Draft), Sustainable Development Knowledge Platform (United Nations, 2015). https://unstats.un.org/unsd/broaderprogress/pdf/technical\%20report $\% 20$ of $\% 20$ the $\% 20$ unsc $\% 20$ bureau\%20(final).pdf.

2. Moscow Declaration of INTOSAI 2019. https://ach.gov.ru/upload/medialibrary/news/Mocковская_декларация.pdf.

3. Yu. V. Guseva and N. S. Stolyarov, "Strategic audit: Foreign experience," Vestn. AKSOR, No. 1, 134-145 (2010).

4. Montesquieu, The Spirit of Laws (1750; Mysl', Moscow, 1999).

5. Mexican Declaration on the Independence of Supreme Audit Institutions (2007). https://www.eurosai.org/handle404?exporturi=/export/sites/eurosai/. content/documents/others/ISSAI/ISSAI-10-Ruso.pdf.

6. Sun Yat-sen, Five-Power Constitution (Nauka, Moscow, 1985), pp. 641-656 [in Russian].

7. M. V. Baglai, Constitutional Law of the Russian Federation: Handbook for Universities, 6th ed. (Norma, Moscow, 2007).

8. A. S. Burmistrov, "Control power in Russia," Gos. Vlast' Mestnoe Samoupr., No. 10, 7-10 (2010).

9. I. P. Okulich, Constitutional and Legal Foundations of the Activities of State Control and Accounting Bodies in the Russian Federation (REKPOL, Chelyabinsk, 2008).

10. S. N. Stanskikh, "Federal government bodies with a special status in the system of separation of powers," Gos. Vlast' Mestnoe Samoupr., No. 1, 8-9 (2007).

11. V. E. Chirkin, Political Science: Handbook, 2nd ed. (Yurist, Moscow, 2000).

12. S. A. Belanovskii, M. E. Dmitriev, V. M. Komarov, M. O. Komin, V. A. Kotsyubinskii, and A. V. Nikol'skaya, Analysis of the Factors for the Implementation of Top-Level Strategic Planning Documents (St. Petersburg, 2016) [in Russian]. https://www.csr.ru/uploads/2016/12/Report-on-strategy.pdf.

13. Ya. I. Kuz'minov and A. B. Zhulin, Administrative Reform and Reduction of Control and Supervisory Functions. Theses of the Report "Perspectives of Administrative Reform." https://www.hse.ru/data/2016/ 06/21/1116116123/Administrativnaya\%20reforma.pdf.

14. Confucius. Conversations and Judgments. https:// web.archive.org/web/20170601012248/.

Translated by S. Avodkova 